\title{
Subnormal vitamin B12 concentrations and anaemia in older people: a systematic review
}

\author{
Wendy PJ den Elzen*1, Gerda M van der Weele1, Jacobijn Gussekloo', Rudi GJ Westendorp² and Willem JJ Assendelft'
}

\begin{abstract}
Background: Pernicious anaemia is undeniably associated with vitamin B12 deficiency, but the association between subnormal vitamin B12 concentrations and anaemia in older people is unclear. The aim of this systematic review was to evaluate the association between subnormal vitamin B12 concentrations and anaemia in older people.

Methods: Clinical queries for aetiology and treatment in bibliographic databases (PubMed [01/1949-10/2009]; EMBASE [01/1980-10/2009]) were used. Reference lists were checked for additional relevant studies. Observational studies ( $\geq 50$ participants) and randomized placebo-controlled intervention trials (RCTs) were considered.

Results: 25 studies met the inclusion criteria. Twenty-one observational cross-sectional studies (total number of participants $n=16185$ ) showed inconsistent results. In one longitudinal observational study, low vitamin B12 concentrations were not associated with an increased risk of anaemia (total $n=423$ ). The 3 RCTs (total $n=210$ ) were well-designed and showed no effect of vitamin B12 supplementation on haemoglobin concentrations during followup in subjects with subnormal vitamin B12 concentrations at the start of the study. Due to large clinical and methodological heterogeneity, statistical pooling of data was not performed.

Conclusions: Evidence of a positive association between a subnormal serum vitamin B12 concentration and anaemia in older people is limited and inconclusive. Further well-designed studies are needed to determine whether subnormal vitamin B12 is a risk factor for anaemia in older people.
\end{abstract}

\section{Background}

Pernicious anaemia is a form of anaemia that is undeniably associated with vitamin B12 deficiency. Finding the cure for pernicious anaemia even led to the discovery of vitamin B12 [1-7]. Nowadays, vitamin B12 deficiency is not only associated with (pernicious) anaemia, but is also linked with other conditions such as dementia, neuropathy and subacute combined degeneration of the spinal cord [8-11]. Therefore, individuals with low serum concentrations of vitamin B12 are frequently given vitamin B12 supplements [10-12]. Also, since low serum vitamin B12 concentrations are very common in older individuals [13], screening older people for vitamin B12 deficiency has often been recommended [14,15].

Although the biological role of vitamin B12 in haematopoiesis is well-defined [11,16-18], the outcomes of some studies cast doubt on the relationship between low

* Correspondence: w.p.j.den_elzen@lumc.nl

1 Department of Public Health and Primary Care, Leiden University Medical Center, Leiden, The Netherlands

Full list of author information is available at the end of the article vitamin B12 concentrations and anaemia in older individuals $[19,20]$. The association between low vitamin B12 and anaemia has become even more difficult to study because various cut-off values for serum vitamin B12 are used and serum concentrations of vitamin B12 appear not to be an accurate reflection of vitamin B12 status at the tissue level $[8,21,22]$.

Therefore, in order to evaluate the association between subnormal vitamin B12 concentrations and anaemia in older subjects, we performed a systematic review of relevant observational (cross-sectional and longitudinal) studies and randomized placebo-controlled trials that have been published in the medical literature to date.

\section{Methods}

Criteria for considering studies for this review

All published cross-sectional and longitudinal observational studies in older individuals (mean or median age $\geq 60$ years) on the association between vitamin B12 and anaemia were considered for inclusion in this review. The exact definitions of vitamin B12 deficiency and anaemia 
had to be clearly stated. Observational studies with less than 50 participants were excluded.

In addition, we considered all randomized controlled trials (RCTs) where subjects 60 years of age and over were treated with vitamin B12 (any dose and any form of administration) and were compared with subjects who were given a placebo. Studies in which patients had received vitamin $B 12$ treatment prior to the study were excluded. Trials in which combinations of vitamin B12 and folic acid were administered were also excluded.

\section{Search strategy}

We used predefined clinical queries (both sensitive and specific) for aetiology and treatment as provided in PubMed (January 1949 - October 2009) and EMBASE (January 1980 - October 2009) using relevant MeSHheadings and free text words for vitamin B12 and anaemia. Case reports and letters were excluded. We restricted our search to articles published in English, French, German and Dutch. The exact search strategies are presented in Additional file 1 (PubMed) and Additional file 2 (EMBASE). Articles in which the mean or median age of the study population was less than 60 years were excluded by hand during the selection process.

\section{Selection of studies}

All titles and abstracts retrieved from the electronic databases were initially assessed by the first author. In cases of uncertainty of relevance, the titles and abstracts were also independently assessed by the second author. Disagreement was resolved by consensus. Full copies were obtained for papers that were potentially relevant to our review. Both authors independently assessed these papers and disagreement was again resolved by consensus. Furthermore, reference lists given in the full papers were scrutinized by the first author for additional relevant studies.

\section{Data extraction}

From the papers describing observational studies, (i) mean/median (SD) vitamin B12 concentrations in anaemic and non-anaemic older subjects, (ii) mean/median (SD) haemoglobin concentrations in older subjects with vitamin B12 deficiency and subjects with normal vitamin B12 concentrations, (iii) percentage of subjects with vitamin B12 deficiency in anaemic and non-anaemic older subjects, (iv) percentage of subjects with anaemia in vitamin B12 deficient and non-deficient older subjects, or (v) the correlation between vitamin B12 concentrations and haemoglobin concentrations were extracted. Data describing the correlation between vitamin B12 concentrations and mean corpuscular volume (MCV) or macrocytosis were also extracted, if available. From the papers describing intervention studies, we extracted pre- and post-treatment mean haemoglobin concentrations, mean proportions of haematocrit and mean $\mathrm{MCV}$, or the change in these variables during treatment. Measures of association between low vitamin B12 concentrations and anaemia and mean corpuscular volume (MCV), and indicators of statistical significance were also extracted.

\section{Quality assessment and level of evidence}

The first and second author independently assessed the quality of every included study. The included longitudinal study that had been performed by our own research group was also independently assessed by an independent investigator (DAWM van der Windt). Disagreement was resolved by consensus.

The methodological quality assessment of the observational studies was based on previously developed checklists for such studies [23,24]. For the cross-sectional observational studies, we only used items on the checklists relevant to the quality assessment of cross-sectional studies, including the use of valid selection criteria, a response of $\geq 80 \%$, the use of a valid and reproducible method to assess the exposure, the use of a valid and reproducible method to assess the outcome, the use of new and incident patients, adjustment for possible confounders, and the inclusion of more than 100 subjects.

One point was awarded for each question that was answered by 'yes'. The answers 'no' or 'unknown' were given 0 points. The maximum total score possible for cross-sectional studies was 7 points. Cross-sectional studies that scored 5 points or more in terms of their quality assessment were considered 'high quality'.

For the longitudinal studies, we added two items to the quality assessment, namely a response at main moment of follow-up $\geq 80 \%$, and data collection for $\geq 1$ year.

Again, one point was awarded for each question that was answered by 'yes' and the answers 'no' or 'unknown' were given 0 points. The maximum total score possible for longitudinal studies was 9 points. Longitudinal studies that scored 7 points or more in their quality assessment were considered 'high quality'.

The quality assessment of the intervention studies was carried out according to the criteria developed by Jadad and colleagues [25]. This checklist includes three main questions on the reporting of randomization, blinding, and withdrawals and dropouts.

For each question that was answered by 'yes', one point was awarded. An additional point was given if the method used to generate the sequence of randomization was described and was appropriate or if the method of double blinding was described and was appropriate. One point was deducted if the method to generate the sequence of randomization was described and it was inappropriate or if the method of double blinding was described and it was inappropriate. The maximum total score possible was 5 points. Intervention studies which 
scored 3 points or more for their quality assessment were considered 'high quality'.

The level of evidence for the association between a subnormal vitamin B12 and anaemia was graded according to the criteria described by the GRADE working group, separately for the observational studies and the intervention studies [26].

\section{Results}

\section{Selection of studies}

Electronic searches of PubMed and EMBASE databases identified 3084 titles and abstracts of papers relevant to the present review. We obtained 350 full papers; 21 of which met our inclusion criteria. Four additional papers were obtained by examining the reference lists given in these chosen papers. A schematic representation of the search process is described in Figure 1.

\section{Observational studies}

Twenty-one cross-sectional observational studies with a total number of 16185 participants were included (Table 1) [27-47]. Eleven studies included participants from the general population [27-37]. Ten studies investigated the association between vitamin B12 and anaemia in hospitalized or institutionalized subjects [38-47]. Detailed information about the studies can be found in Additional file 3.

We did not try to retrieve a pooled estimate of the results of the cross-sectional studies for the following reasons: 1 ) the studies had been performed in very different patient populations, 2) the investigators had used different cut-off points for vitamin B12 deficiency and anaemia, 3) different effect estimates had been calculated and 4) the overall methodological quality was poor. This clinical and methodological heterogeneity could not be solved by any subgroup analysis.

Of the 21 observational cross-sectional studies, 8 studies were of low quality ("see Additional file 4") $[30,32,37,42-44,46,47]$. The remaining 13 studies of high quality differed substantially in sample size, criteria for low vitamin B12 status and level of adjustment for confounders [27-29,31,33-36,38-41,45]. The studies showed inconsistent results with regards to the association between subnormal vitamin B12 concentrations or vitamin B12 deficiency and anaemia in older subjects. In three studies, an association between subnormal vitamin B12 and anaemia was found (Clarke et al [29], Morris et al. [36] and Wang et al [46]). For seven studies, the presence of an association was not clear because conflicting findings regarding the presence of an association were reported (Allain et al. [27], Johnson et al. [32], McLennan et al. [35], Penninx et al. [37], Joosten et al. [40], Kwok et al. [41], and Prayaharong et al. [44]). Eleven studies did not find an association between subnormal vitamin B12 and anaemia (Bjorkegren et al. [28], Hin et al. [30], Hvas et al. [31], Lippi et al. [33], Loikas et al. [34], Bisbe et al. [38], Chui et al. [39], Metz et al. [42], Mooney et al. [43], Stott et al. [45], and Witte et al. [47]).

Allain et al., McLennan et al. and Joosten et al. had applied the lowest serum vitamin B12 cut-off points for vitamin B12 deficiency $(100 \mathrm{pg} / \mathrm{mL}, 140 \mathrm{pg} / \mathrm{mL}$ and 110 $\mathrm{pmol} / \mathrm{L}$ respectively) $[27,35,40]$. In these three studies, the presence of an association between vitamin B12 deficiency and anaemia was not clear, because conflicting findings regarding the presence of an association were reported $[27,35,40]$. In the two largest population-based studies by Clarke et al. and Morrison et al., subjects with low vitamin B12 concentrations had an increased risk of having anaemia, also after extensive adjustment for confounders [29,36], but an even larger study in hospitalized older persons by Chui et al. did not show any association between vitamin B12 deficiency and anaemia [39]. Similar inconsistencies were found with respect to the association between subnormal vitamin B12 concentrations and MCV.

Our own study appeared to be the only longitudinal study on the effect of low vitamin B12 concentrations $(<150 \mathrm{pmol} / \mathrm{L})$ on developing anaemia in a populationbased sample of 85-year-old subjects $(\mathrm{n}=423)$ [48]. Detailed information about the study and the quality assessment can be found in Additional file 5 and Additional file 6, respectively. After adjustment for possible confounding variables, low vitamin B12 concentrations were not associated with an increased risk of having anaemia at baseline (prevalent anaemia) or developing anaemia during follow-up (incident anaemia, Table 1).

\section{Intervention studies}

We found three randomized placebo-controlled trials with a total number of 210 participants that met the inclusion criteria for intervention studies for our review (Table 2) [49-51]. Detailed information about the trials can be found in Additional file 7. These three trials included patients with low or subnormal vitamin B12 levels concentrations at the start of the study. The first trial by Hughes and colleagues included a random sample of 39 persons aged $\geq 65$ years registered at general practices in a town in Wales, UK, that were treated for 4 weeks with intramuscular hydroxocobalamin or placebo. Haemoglobin was measured after 5 weeks [49]. The second trial by Hvas et al. included 140 persons in Aarhus, Denmark, with elevated methylmalonic acid levels (median age 75 years in the treatment group and 74 years in the placebo group) that received weekly intramuscular injections of cyanocobalamin of placebo for 1 month. Haemoglobin was measured after 3 months (13 weeks) [50]. In the third trial by Seal and colleagues, 31 persons in two geriatric hospitals in Melbourne, Australia, (mean age 


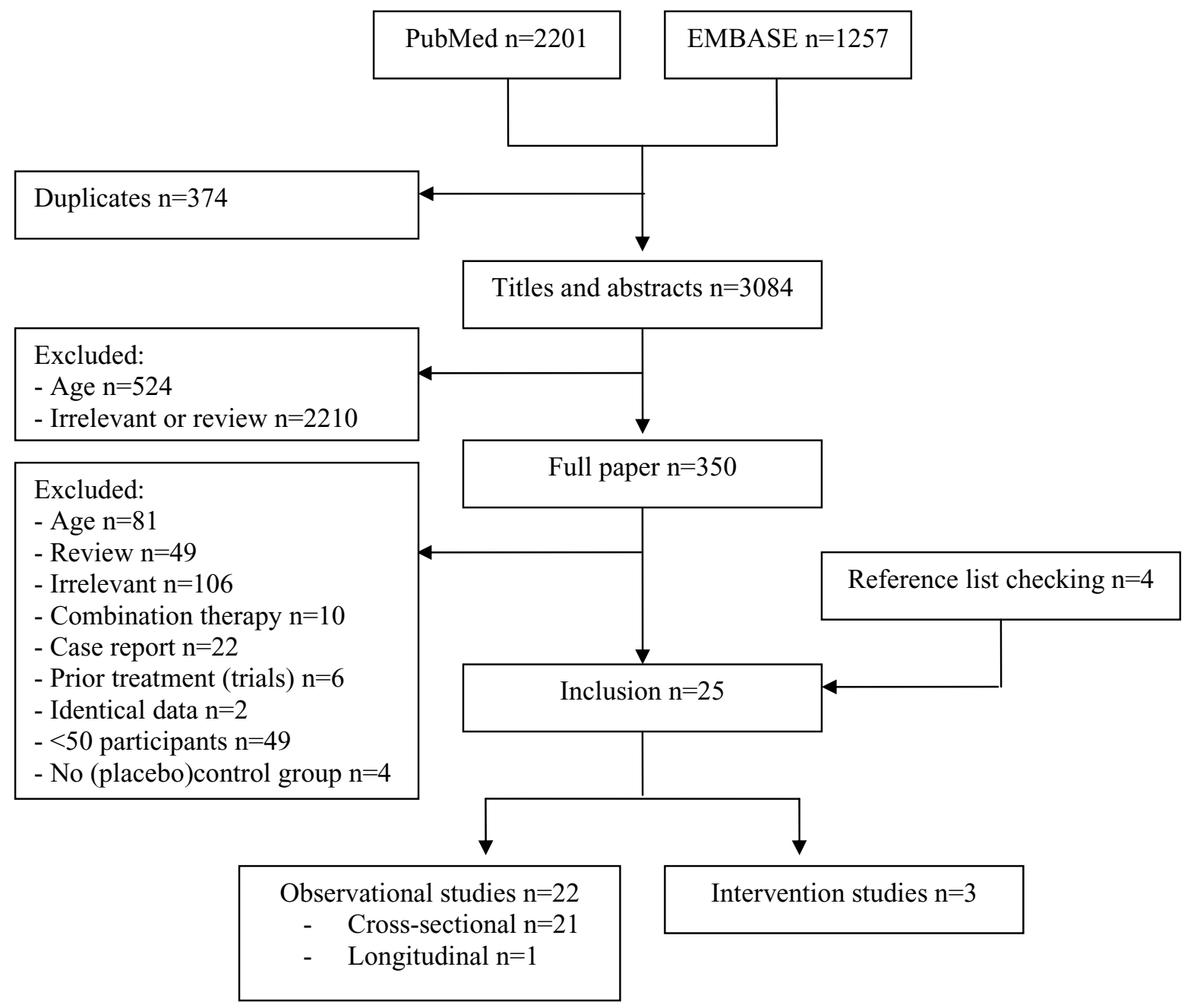

Figure 1 Schematic representation of the selection of publications for review.

$\geq 78$ years) received two different doses of oral cyanocobalamin daily or placebo for 4 weeks [51].

Due to clinical heterogeneity (differences in methods of administration, dose of vitamin B12, outcome measures and treatment follow-up time) we did not combine the results in a meta-analysis. However, all three RCTs, of which two were regarded high quality ("see Additional file 8") [49,50], showed no beneficial effect of vitamin B12 administration on haemoglobin concentrations and MCV. In the study by Hughes et al, there was, on average, a small decrease in haemoglobin level during the trial but the difference between the mean changes in those given vitamin B12 and those given placebo was very small and not statistically significant [49]. In the study by Hvas et al, the change in haemoglobin level was the same in the vitamin B12 group and placebo group [50]. In addition, no differences were observed in the mean change in haemo- globin level in the three treatment groups in the study by Seal et al. [51].

\section{Level of evidence}

Because of serious limitations of study quality and important inconsistency of the observational studies, the level of evidence for an association between subnormal vitamin B12 concentrations and anaemia in older individuals was considered low. Since the quality of two of the RCTs was considered high, the level of evidence for the lack of effect of vitamin B12 administration on haemoglobin in older persons with low vitamin B12 concentrations at the start of the study was considered high.

\section{Discussion}

Although anaemia is regarded as a classic complication of vitamin $\mathrm{B} 12$ deficiency in older people $[8,9,11]$, this systematic review showed that evidence for an association 
Table 1: Summary of the results and quality assessment of the observational studies included in this review

\begin{tabular}{|c|c|c|c|c|c|c|}
\hline Author & $\begin{array}{l}\text { Year of } \\
\text { publication }\end{array}$ & $\begin{array}{l}\text { Sample } \\
\text { size (N) }\end{array}$ & $\begin{array}{l}\text { Age of subjects } \\
\text { (years) }\end{array}$ & Study population & $\begin{array}{c}\text { Presence of an } \\
\text { association } \\
\text { between subnormal } \\
\text { vitamin B12 and } \\
\text { anaemia }\end{array}$ & $\begin{array}{l}\text { Quality } \\
\text { of study* }\end{array}$ \\
\hline
\end{tabular}

Cross-sectional

Population-based

\begin{tabular}{lllllll}
\hline Allain [27] & 1997 & 233 & $\geq 60$, median 72 & $\begin{array}{l}\text { Random sample of older Zimbabweans } \\
\text { (rural and urban). }\end{array}$ & $?$ & 5 \\
\hline Björkegren [28] & 2001 & 224 & $\begin{array}{l}\geq 70, \text { mean 78.0 } \\
(95 \% \mathrm{Cl} 77.2-78.9)\end{array}$ & $\begin{array}{l}\text { Random sample of persons aged 70 years } \\
\text { and over in the Borough of Älvkarleby in } \\
\text { the county of Uppsala, Sweden }\end{array}$ & - & 6 \\
& & &
\end{tabular}

\begin{tabular}{lll}
\hline Clarke [29] 2008 2257 $\quad \begin{array}{l}\geq 65, \text { mean } 79.2 \\
(S D \text { 6.2) }\end{array}$
\end{tabular}

6 sample from general practice registers of people $\geq 65$ years living in Oxford, UK. Banbury B12 Study: Random sample of people aged $\geq 75$ years living in their own homes and registered with general practices in Banbury, Oxfordshire, UK.

\begin{tabular}{llll}
\hline Hin [30] 2006 & 1000 & $\geq 75$, mean 81.4 & Random sample of people $\geq 75$ years \\
& (SD 4.6) & $\begin{array}{l}\text { living at home, registered with general } \\
\text { practitioners in Banbury, England }\end{array}$
\end{tabular}

\begin{tabular}{lll}
\hline Hvas [31] 2005 937 $\begin{array}{l}\text { Median 72, range } \\
19-102\end{array}$ &
\end{tabular}

Subjects with increased MMA $(>0.28$ $\mu \mathrm{mol} / \mathrm{L}$ ) within in Aarhus, Denmark, from 1995-2000.

\begin{tabular}{lllll}
\hline Johnson [32] 2003 & 103 & $\geq 60$, mean 76.4 & $\begin{array}{l}\text { Older individuals enlisted in nutrition } \\
\text { service program in rural northeast } \\
\text { Georgia, USA. }\end{array}$ & $?$
\end{tabular}

\begin{tabular}{|c|c|c|c|c|c|c|}
\hline Lippi[33] & 2009 & 878 & Range 85-101 & $\begin{array}{l}\text { Unselected subjects older than } 85 \text { years, } \\
\text { who were referred by general } \\
\text { practitioners to a laboratory in Verona, } \\
\text { Italy, for routine diagnostic check-up } \\
\text { over a period of } 2 \text { years }\end{array}$ & - & 6 \\
\hline Loikas [34] & 2007 & 1048 & $\geq 65,37 \% \geq 75$ & $\begin{array}{l}\text { Lieto study; unselected population based } \\
\text { health survey in Lieto, Finland. }\end{array}$ & - & 6 \\
\hline McLennan [35] & 1973 & 347 & $>65$ & $\begin{array}{l}\text { Random sample of people }>65 \text { years } \\
\text { living at home in Kilsyth and Northern } \\
\text { Glasgow, UK. }\end{array}$ & $?$ & 5 \\
\hline Morris [36] & 2007 & 1459 & $\begin{array}{l}\geq 60, \text { mean } 70 \\
(\text { SEM } 0.32)\end{array}$ & $\begin{array}{l}\text { Non-institutionalized civilian population } \\
\text { (NHANES), USA. }\end{array}$ & + & 5 \\
\hline Penninx [37] & 2000 & 700 & $\geq 65$, mean 77.3 & $\begin{array}{l}\text { Physically disabled older women living in } \\
\text { the community (Women's Health and } \\
\text { Ageing Study), Baltimore area, USA }\end{array}$ & $?$ & 4 \\
\hline
\end{tabular}


Table 1: Summary of the results and quality assessment of the observational studies included in this review (Continued)

\begin{tabular}{|c|c|c|c|c|c|c|}
\hline \multicolumn{7}{|c|}{ Hospitalized/Institutionalized } \\
\hline Bisbe[38] & 2009 & 599 & Mean 68 (SD 13) & $\begin{array}{l}\text { All consecutive patients scheduled for } \\
\text { major orthopaedic surgery for which } \\
\text { blood was routinely grouped } \\
\text { preoperatively in University Hospital in } \\
\text { Barcelona, Spain. }\end{array}$ & - & 5 \\
\hline Chui [39] & 2001 & 3453 & $48 \%>70$ & $\begin{array}{l}\text { All patients admitted to the Prince of } \\
\text { Wales hospital, Hong Kong, with vitamin } \\
\text { B12 measurements in } 1996 .\end{array}$ & - & 5 \\
\hline Joosten [40] & 1990 & 292 & $>65$ & $\begin{array}{l}\text { Consecutive patients admitted to the } \\
\text { geriatric department of the University } \\
\text { Hospital, Leuven, Belgium }\end{array}$ & $?$ & 5 \\
\hline Kwok [41] & 2002 & 96 & $\begin{array}{l}>55, \text { mean age } \\
>78.0\end{array}$ & $\begin{array}{l}\text { Female ambulatory vegetarians ( }>3 \\
\text { years) in Hong Kong. }\end{array}$ & $?$ & 5 \\
\hline Metz [42] & 1996 & 94 & $\begin{array}{l}\text { Cases: mean } 79.8 \\
\text { Controls: mean } \\
80.7\end{array}$ & $\begin{array}{l}\text { Patients with suspected low vitamin B12 } \\
\text { levels based on clinical examination by } \\
\text { attending staff in Royal Melbourne and } \\
\text { North West hospitals, Australia. If low } \\
\text { vitamin B12: case. If normal vitamin B12: } \\
\text { control. }\end{array}$ & - & 2 \\
\hline Mooney [43] & 2004 & 905 & $65-85$ & $\begin{array}{l}\text { Hospitalized patients in Belfast, Ireland, } \\
\text { who had vitamin B12, folate, } \mathrm{Hb}, \mathrm{MCV} \\
\text { and ferritin measured within } \pm 4 \text { days of } \\
\text { each other in February-July } 2003\end{array}$ & - & 3 \\
\hline $\begin{array}{l}\text { Prayurahong } \\
{[44]}\end{array}$ & 1993 & 147 & $\geq 60$ & $\begin{array}{l}\text { Subjects visiting clinic for older } \\
\text { individuals in Rajvithi Hospital, Bangkok }\end{array}$ & $?$ & 3 \\
\hline Stott [45] & 1997 & 290 & Range $62-110$ & $\begin{array}{l}\text { Consecutive new referrals to a geriatric } \\
\text { medical unit in Glasgow, Scotland. }\end{array}$ & - & 5 \\
\hline Wang [46] & 2009 & 827 & $\begin{array}{l}\text { Mean } 77.1(\mathrm{SD} \\
7.5) \text {, range } 60-96\end{array}$ & $\begin{array}{l}\text { Patients in the department of Neurology } \\
\text { of Shanghai Punan Hospital, Shanghai, } \\
\text { China. }\end{array}$ & + & 4 \\
\hline Witte [47] & 2004 & 296 & Mean $72.5(10.3)$ & $\begin{array}{l}\text { Consecutive patients with chronic heart } \\
\text { failure attending a heart failure clinic in } \\
\text { Cottingham, UK }\end{array}$ & - & 4 \\
\hline
\end{tabular}

\section{Longitudinal}

Den Elzen [48] $\quad 2008 \quad 423 \quad 85$

All 85-year-old inhabitants of Leiden, the 
Table 2: Summary of the results and quality assessment of the intervention studies included in this review

\begin{tabular}{|c|c|c|c|c|c|c|c|}
\hline Author & $\begin{array}{l}\text { Year of } \\
\text { publication }\end{array}$ & $\begin{array}{l}\text { Sample } \\
\text { size (N) }\end{array}$ & $\begin{array}{l}\text { Age of subjects } \\
\text { (years) }\end{array}$ & Study population & Intervention & $\begin{array}{l}\text { Effectiveness of } \\
\text { vitamin B12 } \\
\text { treatment on } \\
\text { haemoglobin } \\
\text { concentrations }\end{array}$ & $\begin{array}{l}\text { Quality of } \\
\text { study* }\end{array}$ \\
\hline Hughes [49] & 1970 & $\begin{array}{l}\text { Placebo } n=19 \\
\text { Treatment } n=20\end{array}$ & $\geq 65$ & $\begin{array}{l}\text { Random sample of subjects aged } \geq 65 \text { years } \\
\text { from general practices in a town in Wales, UK. } \\
\text { Subjects with vitamin B12 level }<150 \mathrm{pg} / \mathrm{mL} \\
\text { were invited to participate in the trial. None } \\
\text { had anaemia or evidence of vitamin B12 } \\
\text { neuropathy and none was taking drugs that } \\
\text { might interfere with vitamin B12 assays or } \\
\text { anticonvulsants that might reduce the serum } \\
\text { vitamin B12 level. }\end{array}$ & $\begin{array}{l}\text { Intramuscular } \\
\text { hydroxocobalamin }(1000 \mu \mathrm{g}) \text {, } \\
\text { twice in the first week, and then } \\
\text { at weekly intervals for a further } \\
\text { four weeks or placebo } \\
\text { containing a matching solution } \\
\text { of phenol red } \\
\text { (phenylsulphonphtalein } \\
0.075 \% \text { ) }\end{array}$ & - & 4 points \\
\hline Hvas [50] & 2001 & $\begin{array}{l}\text { Placebo } n=70 \\
\text { treatment } n=70\end{array}$ & $\begin{array}{l}\text { Treatment group: } \\
\text { Median } 75 \text { (range } \\
\text { 19-92) Placebo } \\
\text { group: } 74 \text { (range } \\
\text { 33-88) }\end{array}$ & $\begin{array}{l}140 \text { subjects in Aarhus, Denmark, with } \\
\text { elevated methylmalonic acid (P-MMA, 0.40- } \\
2.00 \mu \mathrm{mol} / \mathrm{L} \text { ) which had not received prior } \\
\text { vitamin B12 treatment. Participants were } \\
\text { enrolled between November } 1998 \text { and March } \\
2000 \text {. Exclusion criteria: low Hb levels, low } \\
\text { ferritin levels, TSH } \geq 4.1 \mathrm{mIU} / \mathrm{L} \text {, high creatinine } \\
\text { levels, life-threatening disease, treatment with } \\
\text { anticoagulants, tropical atoxic neuropathy. }\end{array}$ & $\begin{array}{l}\text { Weekly intramuscular injections } \\
\text { of } 1 \mathrm{mg} \text { cyanocobalamin }(n=70) \\
\text { or placebo containing } 1 \mathrm{~mL} \text { of } \\
\text { isotonic sodium chloride }(n=70) \\
\text { for } 1 \text { month }\end{array}$ & - & 4 points \\
\hline Seal [51] & 2002 & $\begin{array}{l}\text { Placebo } n=11, \text { oral } \\
\text { vitamin } B 1210 \mu \mathrm{g} n= \\
10, \text { oral vitamin } B 12 \\
50 \mu \mathrm{g}, \mathrm{n}=10\end{array}$ & $\begin{array}{l}\text { Mean age } \\
\text { placebo } 78, \\
\text { vitamin B12 } 10 \mu \mathrm{g} \\
82, \text { vitamin B12 } \\
50 \mu \mathrm{g} 85\end{array}$ & $\begin{array}{l}31 \text { patients in two geriatric hospitals in } \\
\text { Melbourne, Australia with subnormal serum } \\
\text { vitamin B12 (100-150 pmol/L) discovered as } \\
\text { part of their clinical assessment. Exclusion } \\
\text { criteria: known neoplasm, life-threatening or } \\
\text { terminal illness, history of malabsorption, } \\
\text { pernicious anaemia, anaemia of other cause, } \\
\text { prior vitamin B12 treatment or vitamin } \\
\text { supplementation, neurological disorder other } \\
\text { than stroke. }\end{array}$ & $\begin{array}{l}\text { Placebo (Australian } \\
\text { Pharmaceutical Formulary (APF) } \\
\text { red mixture and APF } \\
\text { hydrobenzoate compound), } 10 \\
\mu \mathrm{g} \text { oral cyanocobalamin or } 50 \\
\mu \mathrm{g} \text { oral cyanocobalamin daily } \\
\text { for } 4 \text { weeks }\end{array}$ & - & 2 points \\
\hline
\end{tabular}

**Based on checklist from Jadad et al. [25] Higher scores indicate higher quality (range 0-5). Intervention studies that scored 3 points or more were considered 'high quality'. 
between a subnormal serum vitamin B12 concentration and anaemia in older people is limited and inconclusive. A total of 21 observational cross-sectional studies included in our review showed inconsistent results [2747]. Similar inconsistencies were found with respect to the association between subnormal vitamin B12 concentrations and MCV. We identified one longitudinal observational study in older subjects in the general population, in which low vitamin B12 concentrations were not associated with an increased risk of developing anaemia or the change in MCV over time [48]. Interestingly, the three included RCTs, of which two were regarded as high quality RCTs, showed no effect of vitamin B12 administration on haemoglobin concentrations and $\mathrm{MCV}$ in subjects with subnormal vitamin B12 concentrations at the start of the study [49-51], which is unlikely to be explained by insufficient dose of vitamin B12 supplementation, since the RCTs did show changes in vitamin B12, homocysteine and MMA concentrations.

This lack of effect of vitamin B12 treatment on haemoglobin concentrations and MCV in patients with low or subnormal vitamin B12 concentrations is surprising, especially since vitamin B12 has such a well-defined role in haematopoiesis [11,16-18]. However, our results are in line with a systematic review by Oosterhuis and co-workers that showed that the diagnostic value of the mean corpuscular volume in the detection of vitamin B12 deficiency is poor [52]. There are two possible explanations why evidence of an association between subnormal vitamin B12 concentrations and anaemia is lacking. First, the studies included in the review had used many different tests to measure the concentration of serum vitamin B12, ranging from microbiological assays with L. leichmannii to radio immunoassays, and had applied different cut-off points for vitamin B12 deficiency. This may have led to misclassification in the diagnosis of vitamin B12 deficiency and, as a result, to dilution of the association between vitamin B12 deficiency and anaemia. However, the 3 studies that had applied the lowest cut-off point for vitamin B12 deficiency, in which therefore the strongest associations were to be expected, did not report clear associations between vitamin B12 deficiency and anaemia $[27,35,40]$. The second explanation is that a subnormal vitamin B12 concentration alone is not a sufficient cause to develop anaemia. Other genetic or environmental factors may be necessary to develop anaemia in the presence of subnormal vitamin B12 concentrations. A similar explanation has been proposed for the lack of association between the $\mathrm{C} 282 \mathrm{Y}$ mutation of the hereditary haemochromatosis gene and mortality in old age [53].

Several difficulties were encountered when conducting this systematic review. These are similar to the problems Oosterhuis and co-workers faced when writing their sys- tematic review on the diagnostic accuracy of the mean corpuscular volume in the detection of vitamin B12 deficiency [52]. Most importantly, the relation between low vitamin B12 concentrations and anaemia was not an explicit research question in most of the studies included in the present review, which could have resulted in insufficient statistical power to detect an association.

The diagnosis of vitamin B12 deficiency is a major concern in medical literature and its difficulties have been addressed thoroughly by others in the field [9,54]. Our systematic literature search identified only 25 relevant studies to review the association between vitamin B12 and anaemia in older people. In those studies many different assays were used to measure vitamin B12 and haemoglobin concentrations and varying cut-off points were applied to define vitamin B12 deficiency and anaemia. This considerably limited the comparability of the studies and emphasizes the need for a clear and globally used definition of (sub)normal vitamin B12 concentrations, either based on serum vitamin B12 concentrations alone, or in combination with elevated homocysteine or methylmalonic acid concentrations [9].

Furthermore, the clinical and methodological heterogeneity in the included observational studies prevented us from performing statistical pooling of data and thus drawing definite conclusions. The participation rates and adjustments for potential confounders, in particular, warrant improvement in future observational studies. We identified only one longitudinal study on this topic. Although this longitudinal study did not show any association between low serum vitamin B12 concentrations and the future development of anaemia, this study involved subjects aged 85 years only and has to be replicated in younger age groups (60-85 years) before more definite conclusions can be drawn.

We found 3 placebo-controlled trials meeting our inclusion criteria. Participants in these trials received vitamin B12 supplements for 4 weeks and were only followed for 1 to 3 months. Randomized placebo-controlled trials with longer treatment and longer follow-up periods are needed, because the effects of vitamin B12 supplementation on haemoglobin concentrations may only become apparent after 3 months.

Although we did not find an association between subnormal vitamin B12 concentrations and anaemia in older people, this does not imply that patients with pernicious anaemia or age-related food-vitamin B12 malabsorption (with tissue depletion of vitamin B12 and very low vitamin B12 concentrations) will not benefit from vitamin B12 administration, especially since non-placebo-controlled studies showed (large) increases in haemoglobin concentrations or haematocrit after intramuscular or oral vitamin B12 administration in patients with pernicious anaemia or age-related food-vitamin B12 malabsorption 
[55-59]. However, apart from the undisputed reality of pernicious anaemia, the clinical impact of a subnormal vitamin B12 level in older people is unclear, especially since several observational studies and randomized controlled trials also showed no effect of vitamin B12 administration on cognitive function [60-62].

\section{Conclusions}

The studies included in this systematic review indicate that evidence of an association between a subnormal serum vitamin B12 concentration and anaemia in older people is limited and inconclusive. If anything, given the high clinical relevance of our research question, we recommend more well-designed longitudinal observational studies, in younger age groups (60-85 years) especially, and intervention studies of appropriate size and duration with timely follow-up periods to determine whether a subnormal vitamin B12 is a risk factor for anaemia in older people.

\section{Additional material}

Additional file 1 Strategy used to search PubMed database for publications on subnormal vitamin B12 levels and anaemia (carried out October 2009)

Additional file 2 Strategy used to search EMBASE database for publications on subnormal vitamin B12 levels and anaemia (carried out October 2009)

Additional file 3 Observational cross-sectional studies on aetiology of vitamin B12 deficiency and anaemia in older subjects included in the present review

Additional file 4 Quality assessment of cross-sectional observational studies on aetiology of vitamin B12 deficiency and anaemia in elderly subjects included in the present review

Additional file 5 Observational longitudinal study on aetiology of vitamin B12 deficiency and anaemia in older subjects included in the present review

Additional file 6 Quality assessment of longitudinal observational studies on aetiology of vitamin B12 deficiency and anaemia in elderly subjects included in the present review

Additional file 7 Randomized placebo-controlled trials of the effect of vitamin B12 administration on haemoglobin levels in older subjects included in the present review

Additional file 8 Quality assessment of randomized placebo-controlled trials on the effect of vitamin B12 administration on haemoglobin levels in elderly subjects included in the present review

\section{Competing interests}

The authors declare that they have no competing interests.

\section{Authors' contributions}

WPJdE was involved in the conception and design of the review, performed the systematic literature search, assessed all abstracts and full copies, assessed the quality of the included papers, was involved in the analysis and interpretation of the data, and drafted the first version of the manuscript. GMvdW was involved in the conception and design of the review, assessed abstracts and full copies, assessed the quality of the included papers, was involved in the analysis and interpretation of the data, and critically revised the manuscript for important intellectual content. JG was involved in the conception and design of the review, was involved in the interpretation of the data, and critically revised the manuscript for important intellectual content. RGJW was involved in the interpretation of the data and critically revised the manuscript for impor- tant intellectual content. WJJA was involved in the conception and design of the review, was involved in the analysis and interpretation of the data, and critically revised the manuscript for important intellectual content. All authors read and approved the final manuscript.

\section{Acknowledgements}

We thank Mrs DL Brand-de Heer from the Walaeus Library of the Leiden University Medical Center for her advice in the construction of the electronic search strategies. We also thank Prof. DAWM van der Windt for her advice on the inclusion criteria and quality assessment of the observational studies and the independent quality assessment of our longitudinal observational study. Funding

This study had no external funding source.

\section{Author Details}

1Department of Public Health and Primary Care, Leiden University Medical Center, Leiden, The Netherlands and ${ }^{2}$ Department of Gerontology and Geriatrics, Leiden University Medical Center, Leiden, The Netherlands

Received: 1 December 2009 Accepted: 23 June 2010

Published: 23 June 2010

\section{References}

1. Biermer A: Uber eine Form von progressiver peniciöser Anämie. Schweiz Arzte 1872, 2:15-17.

2. Minot GR, Murphy WP: Treatment of pernicious anemia by a special diet. JAMA 1926, 87:470-476.

3. Lester-Smith E: Purification of the anti-pernicious anaemia factor from liver extracts. Nature 1948, 161:638-639.

4. Rickes EL, Brink NG, Koniusky FR, Wood TR, Folkers K: Crystalline vitamin B12. Science 1948, 107:396-397.

5. Okuda K: Discovery of vitamin B12 in the liver and its absorption factor in the stomach: a historical review. J Gastroenterol Hepatol 1999, 14:301-308.

6. Chanarin I: Historical review: a history of pernicious anaemia. $\mathrm{Br} J$ Haematol 2000, 111:407-415.

7. Whittingham S, Mackay IR: Autoimmune gastritis: historical antecedents, outstanding discoveries, and unresolved problems. Int Rev Immunol 2005, 24:1-29.

8. Stabler SP, Allen RH, Savage DG, Lindenbaum J: Clinical spectrum and diagnosis of cobalamin deficiency. Blood 1990, 76:871-881.

9. Andres $E$, Loukili NH, Noel E, Kaltenbach G, Abdelgheni MB, Perrin AE, Noblet-Dick M, Maloisel F, Schlienger JL, Blickle JF: Vitamin B12 (cobalamin) deficiency in elderly patients. CMAJ 2004, 171:251-259.

10. Wolters M, Strohle A, Hahn A: Cobalamin: a critical vitamin in the elderly. Prev Med 2004, 39:1256-1266.

11. Babior BM, Bunn HF: Megaloblastic Anemias. 2004, 16:602-607.

12. Kolnaar BGM, Van Wijk MAM, Pijnenborg L, Assendelft WJJ: [Summary of the Dutch College of General Practitioners' practice guideline 'anaemia']. Ned Tijdschr Geneeskd 2003, 147:1956-1961.

13. Pennypacker LC, Allen RH, Kelly JP, Matthews LM, Grigsby J, Kaye K, Lindenbaum J, Stabler SP: High prevalence of cobalamin deficiency in elderly outpatients. J Am Geriatr Soc 1992, 40:1 197-1204.

14. Clarke R, Refsum H, Birks J, Evans JG, Johnston C, Sherliker P, Ueland PM, Schneede J, McPartlin J, Nexo E, Scott JM: Screening for vitamin B-12 and folate deficiency in older persons. Am J Clin Nutr 2003, 77:1241-1247.

15. Stabler SP: Screening the older population for cobalamin (vitamin B12) deficiency. J Am Geriatr Soc 1995, 43:1290-1297.

16. Martens $\mathrm{JH}$, Barg H, Warren MJ, Jahn D: Microbial production of vitamin B12. Appl Microbiol Biotechnol 2002, 58:275-285.

17. Samson $D$, Halliday $D$, Chanarin I: Reversal of ineffective erythropoiesis in pernicious anaemia following vitamin B12 therapy. Br J Haematol 1977, 35:217-224.

18. Myhre E: Studies on megaloblasts in vitro. I. Proliferation and destruction of nucleated red cells in pernicious anemia before and during treatment with vitamin B 12. Scand J Clin Lab Invest 1964, 16:307-319.

19. Carmel R: Pernicious anemia. The expected findings of very low serum cobalamin levels, anemia, and macrocytosis are often lacking. Arch Intern Med 1988, 148:1712-1714. 
20. Lindenbaum J, Healton EB, Savage DG, Brust JC, Garrett TJ, Podell ER, Marcell PD, Stabler SP, Allen RH: Neuropsychiatric disorders caused by cobalamin deficiency in the absence of anemia or macrocytosis. NEngl J Med 1988, 318:1720-1728.

21. Savage DG, Lindenbaum J, Stabler SP, Allen RH: Sensitivity of serum methylmalonic acid and total homocysteine determinations for diagnosing cobalamin and folate deficiencies. Am J Med 1994 96:239-246.

22. Snow CF: Laboratory diagnosis of vitamin B12 and folate deficiency: a guide for the primary care physician. Arch Intern Med 1999, 159:1289-1298.

23. van der Windt DA, Zeegers MP, Kemper HC, Assendelft WJ, Scholten RJ: [Practice of systematic reviews. VI. Searching, selection and methodological evaluation of etiological research]. Ned Tijdschr Geneeskd 2000, 144:1210-1214.

24. van der Windt DA, Thomas E, Pope DP, de Winter AF, Macfarlane GJ, Bouter LM, Silman AJ: Occupational risk factors for shoulder pain: a systematic review. Occup Environ Med 2000, 57:433-442.

25. Jadad AR, Moore RA, Carroll D, Jenkinson C, Reynolds DJ, Gavaghan DJ, McQuay HJ: Assessing the quality of reports of randomized clinical trials: is blinding necessary? Control Clin Trials 1996, 17:1-12.

26. Atkins D, Best D, Briss PA, Eccles M, Falck-Ytter Y, Flottorp S, Guyatt GH, Harbour RT, Haugh MC, Henry D, Hill S, Jaeschke R, Leng G, Liberati A, Magrini N, Mason J, Middleton P, Mrukowicz J, O'Connell D, Oxman AD, Phillips B, Schunemann HJ, Edejer TT, Varonen H, Vist GE, Williams JW Jr, Zaza S: Grading quality of evidence and strength of recommendations. BMJ 2004, 328:1490-1494.

27. Allain TJ, Gomo Z, Wilson AO, Ndemera B, Adamchak DJ, Matenga JA: Anaemia, macrocytosis, vitamin B12 and folate levels in elderly Zimbabweans. Cent Afr J Med 1997, 43:325-328.

28. Bjorkegren K, Svardsudd K: Serum cobalamin, folate, methylmalonic acid and total homocysteine as vitamin B12 and folate tissue deficiency markers amongst elderly Swedes--a population-based study. J Intern Med 2001, 249:423-432.

29. Clarke R, Sherliker P, Hin H, Molloy AM, Nexo E, Ueland PM, Emmens K, Scott JM, Evans JG: Folate and vitamin B12 status in relation to cognitive impairment and anaemia in the setting of voluntary fortification in the UK. Br J Nutr 2008, 100:1-6.

30. Hin H, Clarke R, Sherliker P, Atoyebi W, Emmens K, Birks J, Schneede J, Ueland PM, Nexo E, Scott J, Molloy A, Donaghy M, Frost C, Evans JG: Clinical relevance of low serum vitamin B12 concentrations in older people: the Banbury B12 study. Age Ageing 2006, 35:416-422.

31. Hvas AM, Nexo E: Holotranscobalamin--a first choice assay for diagnosing early vitamin B deficiency? J Intern Med 2005, 257:289-298

32. Johnson MA, Hawthorne NA, Brackett WR, Fischer JG, Gunter EW, Allen $\mathrm{RH}$, Stabler SP: Hyperhomocysteinemia and vitamin B-12 deficiency in elderly using Title Illc nutrition services. Am J Clin Nutr 2003, 77:211-220.

33. Lippi G, Montagnana M, Targher G, Guidi GC: Vitamin B12, folate, and anemia in old age. Arch Intern Med 2009, 169:716.

34. Loikas S, Koskinen P, Irjala K, Lopponen M, Isoaho R, Kivela SL, Pelliniemi TT: Vitamin B12 deficiency in the aged: a population-based study. Age Ageing 2007, 36:177-183.

35. McLennan WJ, Andrews GR, Macleod C, Caird Fl: Anaemia in the elderly. Q J Med 1973, 42:1-13.

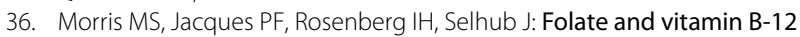
status in relation to anemia, macrocytosis, and cognitive impairment in older Americans in the age of folic acid fortification. Am J Clin Nutr 2007, 85:193-200.

37. Penninx BW, Guralnik JM, Ferrucci L, Fried LP, Allen RH, Stabler SP: Vitamin $\mathrm{B}(12)$ deficiency and depression in physically disabled older women: epidemiologic evidence from the Women's Health and Aging Study. Am J Psychiatry 2000, 157:715-721.

38. Bisbe E, Castillo J, Saez M, Santiveri X, Ruiz A, Munoz M: Prevalence of preoperative anemia and hematinic deficiencies in patients scheduled for elective major orthopedic surgery. Transfus Altern Transfus Med 2008, 10:166-173

39. Chui CH, Lau FY, Wong R, Soo OY, Lam CK, Lee PW, Leung HK, So CK, Tsoi WC, Tang N, Lam WK, Cheng G: Vitamin B12 deficiency - Need for a new guideline. Nutrition 2001, 17:917-920.

40. Joosten E, Pelemans W, Hiele M, Goossens W: [Vitamin B12 (cobalamin)deficiency in the elderly]. Ned Tijdschr Geneeskd 1990, 134:652-656.
41. Kwok T, Cheng G, Woo J, Lai WK, Pang CP: Independent effect of vitamin B12 deficiency on hematological status in older Chinese vegetarian women. Am J Hematol 2002, 70:186-190.

42. Metz J, Bell AH, Flicker L, Bottiglieri T, Ibrahim J, Seal E, Schultz D, Savoia H, McGrath KM: The significance of subnormal serum vitamin B12 concentration in older people: a case control study. J Am Geriatr SoC 1996, 44:1355-1361.

43. Mooney KM, Young IS, Patterson CC, Cuskelly GJ: Vitamin B12 status in elderly subjects with low haemoglobin. Proc Nutr Soc 2004, 63:77A.

44. Prayurahong B, Tungtrongchitr R, Chanjanakijskul S, Lertchavanakul A, Supawan V, Pongpaew P, Vudhivai N, Hempfling AA, Schelp FP, Migasena P: Vitamin B12, folic acid and haematological status in elderly Thais. J Med Assoc Thai 1993, 76:71-78.

45. Stott DJ, Langhorne P, Hendry A, McKay PJ, Holyoake T, Macdonald J, Lucie N: Prevalence and haemopoietic effects of low serum vitamin B12 levels in geriatric medical patients. Br J Nutr 1997, 78:57-63.

46. Wang YH, Yan F, Zhang WB, Ye G, Zheng YY, Zhang XH, Shao F-Y: An investigation of vitamin B12 deficiency in elderly inpatients in neurology department. Neuroscience Bull 2009, 25:209-215.

47. Witte KK, Desilva R, Chattopadhyay S, Ghosh J, Cleland JG, Clark AL: Are hematinic deficiencies the cause of anemia in chronic heart failure? Am Heart J 2004, 147:924-930.

48. den Elzen WP, Westendorp RG, Frolich M, de RW, Assendelft WJ, Gussekloo J: Vitamin B12 and folate and the risk of anemia in old age: the Leiden 85-Plus Study. Arch Intern Med 2008, 168:2238-2244.

49. Hughes D, Elwood PC, Shinton NK, Wrighton RJ: Clinical trial of the effect of vitamin B12 in elderly subjects with low serum B12 levels. Br Med J 1970, 1:458-460.

50. Hvas AM, Ellegaard J, Nexo E: Vitamin B12 treatment normalizes metabolic markers but has limited clinical effect: a randomized placebo-controlled study. Clin Chem 2001, 47:1396-1404.

51. Seal EC, Metz J, Flicker L, Melny J: A randomized, double-blind, placebocontrolled study of oral vitamin B12 supplementation in older patients with subnormal or borderline serum vitamin B12 concentrations. J Am Geriatr Soc 2002, 50:146-151.

52. Oosterhuis WP, Niessen RW, Bossuyt PM, Sanders GT, Sturk A: Diagnostic value of the mean corpuscular volume in the detection of vitamin B12 deficiency. Scand J Clin Lab Invest 2000, 60:9-18.

53. Van Aken MO, de Craen AJ, Gussekloo J, Moghaddam PH, Vandenbroucke JP, Heijmans BT, Slagboom PE, Westendorp RG: No increase in mortality and morbidity among carriers of the C282Y mutation of the hereditary haemochromatosis gene in the oldest old: the Leiden 85-plus study. Eur J Clin Invest 2002, 32:750-754.

54. Carmel R, Green R, Rosenblatt DS, Watkins D: Update on cobalamin, folate, and homocysteine. Hematology (Am Soc Hematol Educ Program) 2003:62-81.

55. Mooney FS, Heathcote JG: Oral treatment of pernicious anaemia: first fifty cases. BrMed J 1966, 1:1149-1151

56. Andres E, Kaltenbach G, Noel E, Noblet-Dick M, Perrin AE, Vogel T, Schlienger JL, Berthel M, Blickle JF: Efficacy of short-term oral cobalamin therapy for the treatment of cobalamin deficiencies related to foodcobalamin malabsorption: a study of 30 patients. Clin Lab Haematol 2003, 25:161-166.

57. Bolaman Z, Kadikoylu G, Yukselen V, Yavasoglu I, Barutca S, Senturk T: Oral versus intramuscular cobalamin treatment in megaloblastic anemia: a single-center, prospective, randomized, open-label study. Clin Ther 2003, 25:3124-3134

58. Kuzminski AM, Del Giacco EJ, Allen RH, Stabler SP, Lindenbaum J: Effective treatment of cobalamin deficiency with oral cobalamin. Blood 1998, 92:1191-1198.

59. Chan JC, Liu HS, Kho BC, Lau TK, Li VL, Chan FH, Leong IS, Pang HK, Lee CK, Liang YS: Pattern of thyroid autoimmunity in chinese patients with pernicious anemia. Am J Med Sci 2009, 337:432-437.

60. Mooijaart SP, Gussekloo J, Frolich M, Jolles J, Stott DJ, Westendorp RG, de Craen AJ: Homocysteine, vitamin B-12, and folic acid and the risk of cognitive decline in old age: the Leiden 85-Plus Study. Am J Clin Nutr 2005, 82:866-871.

61. Ellinson $M$, Thomas J, Patterson A: A critical evaluation of the relationship between serum vitamin $B$, folate and total homocysteine with cognitive impairment in the elderly. J Hum Nutr Diet 2004, 17:371-383. 
62. Malouf R, Areosa SA: Vitamin B12 for cognition. Cochrane Database Syst Rev 2003:CD004326

Pre-publication history

The pre-publication history for this paper can be accessed here:

http://www.biomedcentral.com/1471-2318/10/42/prepub

doi: 10.1186/1471-2318-10-42

Cite this article as: den Elzen et al., Subnormal vitamin B12 concentrations and anaemia in older people: a systematic review BMC Geriatrics 2010, 10:42

Submit your next manuscript to BioMed Central and take full advantage of:

- Convenient online submission

- Thorough peer review

- No space constraints or color figure charges

- Immediate publication on acceptance

- Inclusion in PubMed, CAS, Scopus and Google Scholar

- Research which is freely available for redistribution

Submit your manuscript at www.biomedcentral.com/submit 